\title{
Methodical approaches to the determination of readiness of introduction of «blue ocean» strategy on the enterprises of food industry
}

\author{
Tatiana Belova, Olga Krainiuchenko, \\ Svetlana Rozumei, Olha Pietukhova
}

\section{National University of Food Technologies, Kyiv, Ukraine}

Keywords:

Success

Challenges

Matrix

Strategy

Competition

Article history:

Received

15.05.2020

Received in revised

form 19.10.2020

Accepted

27.12.2020

Corresponding

author:

Svetlana Rozumei

E-mail:

Rozumeisvitlana@, gmail.com

DOI:

$10.24263 / 2304-$

974X-2020-9-4-15

\section{Abstract}

Introduction. The aim of the research is the development of methodical approach to the determination the readiness of introduction of blue ocean strategy on the enterprise.

Materials and methods. The methods of systematization for finding out the factors that carry out influence on the position of enterprise on a way to introduction of «blue ocean» strategy were used. For their distribution on success and challenges the method of comparison was used. The evaluation of factors of successchallenges was carried out by expert methods. The state of industry/ enterprise was determined by matrix method.

Results and discussion. Methodology that allows to define readiness of realization of «blue ocean» strategy is offered. General factors that stipulate the necessity of such strategy realization are outlined. Among them are the most substantial ones and qualificatory for industry / enterprise are elected. They can be both positive (success) and negative (challenges). Their measuring comes true by findingintersection of average estimation (it is determined by expert method) on a weighting coefficient (it is set on the basis of experience of researchers depending on the degree of factors meaningfulness and their influence on the development of industry). With the aim of interpretation of the given results the estimation of industry/ enterprise situation, the use of offered matrix «success-challenges» that has 4 quadrants is offered.

Depending on what field the values of estimations got after success and challenges, drawn conclusion in relation to that, prepared enterprise to introduction of of «blue ocean» strategy or not. There actions that can improve the position of the enterprise on a way to application of this strategy were offered. The worked out methodical approaches on the example of brewing industry of Ukraine and its leading company Private joint stock company «Obolon» were approved and successfully exports the products. The Ukrainian market of brewing industry is the typical representative of environment of red ocean, which is characterized by difficult competition situation with the high level of monopolization, and so for which the application of free market space strategy is actual.

Conclusion. Application of the methodology worked out by authors will allow to define the readiness to the realization of «blue ocean» strategy. 


\section{Introduction}

The characteristic for the whole world strengthening of competition stipulates the necessity to search new decisions, disengage oneself from existing ones, challenge to fundamental principles of business and redistribute borders, creating new markets and industries [1,2]. Many researches of scientists from different countries are sanctified to the idea to create such market space where competition will not dominate [11,33]. It is the best method of development and search of non-standard approaches for business that wants to develop successfully $[3,4,5]$.

One of decisions there can be application of «blue ocean» conception as alternatives of «red ocean» strategy (existent business-environment with exhausting competitive activity) $[7,8,9,10]$. The new market space («blue ocean») can create any type of business, regardless of specific and sizes [33]. The main in the marked conception is persistent aspiration to avoid influence of competitors, to carry conviction in the future $[11,12,13,14]$. It opens wide possibilities, what the results of activity of numerous companies are testifies $[15,16]$.

Without regard to advantages, that gives the use of «blue ocean» strategy, its introduction is related to certain difficulties. The unsolved are remained the questions of readiness of the enterprise to this strategy introduction, presence necessary terms for this purpose $[15,17]$. Especially sharp is this problem for the enterprises of food industry, the competition dominates on these markets [24]. They are interested in that even on some time to have favourable operating conditions $[17,18]$.

Therefore, the research aim is the development of the methodical approach determination the readiness of introduction of blue ocean strategy on the enterprise.

For achievement of this aim, it is necessary to decide such tasks:

- To outline general factors that stipulate the necessity of «blue ocean» creation and to go into details taking into account the specific of the enterprises and industries of food industry and market situation;

- To systematize and divide certain factors into positive (success) and negative (challenges);

- To carry out the evaluation of factors of success and challenges;

- To define position of industry/enterprise on matrix «success-challenges» for finding out the readiness to introduction of «blue ocean» strategy;

- To work out the actions sent to the assistance for creation of new market space.

\section{Methods and materials}

\section{Materials}

The object of the research are the factors that determine readiness of introduction of «blue ocean» strategy on the enterprises of food industry. The subject of the research is: finding out and evaluation of factors of success and challenges that will allow to define the degree of readiness of the enterprise to realization of this strategy; brewing industry of Ukraine and its state; Private joint stock company «Obolon» as the enterprise that works at the market of brewing industry. 


\section{Characteristics of Private joint stock company «Obolon» as the subject of the research}

Private joint stock company «Obolon» is in five of leaders of brewing industry. It is the most progressive private enterprise of beer production, by the national company that is known in the world. The brand portfolio counts over 16 sorts of beer.

Private joint stock company «Obolon» at the Ukrainian beer market is the founder of packing segment by PAT by capacity of 11 and 21 and 30-1 kegs with the capacity of one liter for restaurant business. Three basic competitors of the company are: Private joint stock company «Carlsberg Ukraine», and Limited Liability Company «Persha Pryvatna Broviarnia».

Private joint stock company «Obolon» exports the products to many foreign countries: Canada, Panama, Chile, Great Britain, Japan, Singapore, Vietnam, UAE, Turkey, Germany, France, Switzerland and others [23, 24].

Infobase scientific sources served as $[7,8,9,11,16,18]$ and the results of brewing industry market researches [19, 20, 21, 22, 23, 24].

\section{Methods of research}

Scientific and special methods were used in researches [25].

With the aim, finding out the factors that stipulate the necessity of «blue ocean» creation, that have the influence on industry and enterprise, determine readiness to strategy realization, conducted review of scientific sources. In combination with the method of systematization and comparison, it allowed to distinguish exactly from many possible factors only those that provide success of industry or challenges for it [26, 27, 28].

\section{Method of expert estimations}

Expert methods for evaluation of factors that represented the state of industry and enterprise were used. For all factors there was a certain estimation at 5 scale: « $4 »$ - very high, «4»- high, «3»» - moderate, «2» - weak, «1» - very weak.

In the role of experts leading specialists in this field were invited. The choice of circle and amount of experts came true by determination of establishments that engage in the development of alike questions, and acquaintance, with the publications of leading specialists on issue that is examined.

We made list of specialists, that acquaintances with the state of industry and have corresponding researchhes. According to this list were selected those who were quailified $[29,30]$.

\section{Matrix method}

Matrix methods are taken to the construction of two- or multivariable matrices [32]. They were used for finding out of brewing industry position and the enterprise in the system of coordinates «challenges-success». In the offered matrix on vertical wasp the values of quantitative estimation index of success are put aside, and on horizontal are sizes of quantitative estimation index of challenges. Every quadrant of matrix answers certain position of industry/ enterprise. With the help of this matrix recommendations were developed to introduction of «blue ocean» strategy. 


\section{Methodology of determination the readiness of introduction of blue ocean strategy on the enterprises of food industry}

Detailed analysis of existent theoretical researches in relation to introduction of «blue ocean» conception educed an urgent requirement in the lineation of factors, that inform about inevitability of changes for business, and practical actions that will assist creation of new market space $[2,3,4,5,6]$. The basic methodical approaches determination the readiness of realization of blue ocean strategy on the enterprises of food industry, that are based on marketing researches were offered by us. Within the framework of this methodology we suggest to carry out such steps.

The first step provides the quality of questioning conditions to define factors that predetermine the necessity of introduction of «blue ocean» strategy. To the number of such factors belong: deceleration or reduction the potential for further development of business; threatening changes in consumer environment; strengthening of competition; exceeding supply of commodities/services above demand; distribution and strengthening of processes of globalization; development of technologies for production of plenty of commodities/services; strengthening of price wars; tendency to the increase of production charges $[3,4,6,11,15,16]$. Presence even one of them signals about the necessity of development and passing to new market space. Going out from the situation that was folded in industry and on the enterprise, the list of such factors is formed. They must be gone into detail thus, to take into account the specific of the enterprises and industries of food industry and market situation.

Next step is systematization and division of certain factors on positive and negative that in future will name accordingly as success and challenges. The high level of authenticity of the conducted analysis must be provided by taking into account of greater amount of terms as possible $[10,15,22]$.

By success/ challenges for industry and enterprise it is possible to consider: political stability/instability in the country; favourable/difficult macroeconomic situation; increase/falling of production and consumption of products volumes; stability/instability of national currency; presence/absence of government control of market; small/large concentration of market; subzero/high entrance barriers in industry; large/small prospects of business development; presence/absence of information technologies; large/small stake of innovative products in general production of industry volume; presence/absence of new technologies of products making; stable/unstable demand on the products of industry; falling/increase of price on raw material and others [22, 23, 24].

On the next stage for determination the readiness to realization of strategy, position of industry/company through the quantitative measuring of success - cahllenges by the method of expert estimations is determined.

Leading branch workers that know problems and situation at the corresponding market are attracted for this purpose. Experts estimate influence of every factor on the state of industry/enterprise at 5 scale from «1» (very weak) to «5» (very strong). The average value accounts on the basis of the proposed expert estimations $[29,30]$.

Depending on the degree of meaningfulness of factors and their influence on development of industry (negative or positive), the coefficients of importance (matter from 0,01 to 0,99 , and their sum must be equal 1) are determined. Thus, the special operating of industry conditions, state of economy of the country and political situation, are taken into account $[22,23,24]$.

Finding the sum of products of average experts' estimation on the coefficient of its importance the general estimations of of challenges and success factors are determined. 
With the aim of interpretation of the got results of assessing the situation of industry and enterprise it was worked out and offered the matrix «success-challenge» (Figure 1).

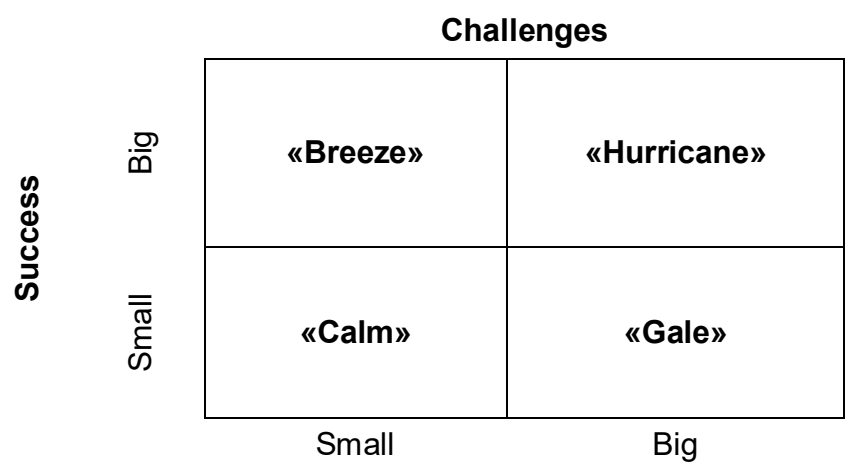

Figure 1. Matrix «success-challenges», designed by the authors

At the place of location of industry/company on the field of matrix determine their position in accordance with offered descriptions of each of four zones of matrix «successchallenges».

Quadrant of matrix «Calm» is the position that is characterized by insignificant success of industry/company at small challenges. Specifies on weak development status and necessity of defence of existent position at the market. For industries/companies that got to the zone «Calm», selective development of those directions that can be effective in the future is offered. It can be strengthening of possibilities for rendering of challenges, but efficiency of these actions is small. The necessity of changes and readiness to them are estimated as remote.

Zone of matrix «Breeze» characterizes position with great successes at insignificant challenges. It is necessary to be concentrated on those prospects that is given by industry/company, and to develop them. At these favourable terms, passing to the «blue ocean» is estimated as the most comfortable. Besides, success in course of time can pass and lot upon them is impossible.

The quadrant of matrix «Hurricane» specifies on the high achievements of industry/company at very large challenges. It warning that maximal success that it attained, is under threat. Changes must be taken place necessarily. It is time, when future position depends on the produced actions. Operating is necessary immediately, while operating conditions are yet comfortable, but they can be quickly finished. And then passing to new reality can be riskier.

Zone of matrix «Gale» is positions that are characterized by very large challenges at small success. The marked position of industry/company abandons not enough chances on providing of comfort transition from the existent state to more perspective. Even at such difficult situation it is needed to search the ways of improvement of development. Passing to the «blue ocean» will take place, however, more time will be passed and terms will be not such advantageous that they could be on the stage «Breeze» or «Hurricane».

It should be noted that at the place of location on matrix «success-challenges» position of industry, by comparison with position of company, can substantially differ. Accordingly, actions that is needed for successful transition from «red» to «blue ocean» will differ (Table $1)$. 
Recommended actions for introduction of «blue ocean» strategy after the matrix «successchallenge, developed by authors

\begin{tabular}{|l|l|}
\hline \multicolumn{1}{|c|}{ Position of industry/company } \\
$\begin{array}{l}\text { Position of industry is stronger } \\
\text { than company position }\end{array}$ & $\begin{array}{l}\text { Search of ways of improvement of enterprise's } \\
\text { position and its market attractiveness. Concentration } \\
\text { of efforts on those possibilities, that is given by } \\
\text { industry, and avoidances of those challenges, into it } \\
\text { runs. } \\
\text { The use of industry potential and internal resources } \\
\text { of business for further development of company. }\end{array}$ \\
\hline $\begin{array}{l}\text { Position of industry is } \\
\text { approximately identical to } \\
\text { company position }\end{array}$ & $\begin{array}{l}\text { Identical position of industry and enterprise. Using } \\
\text { success of both industry and company for future } \\
\text { increase. }\end{array}$ \\
\hline $\begin{array}{l}\text { Position of industry is more } \\
\text { weak than company position }\end{array}$ & $\begin{array}{l}\text { Attempt to avoid those challenges that threaten the } \\
\text { development of industry. Exposure of own ways of } \\
\text { increase, maintenance and strengthening of } \\
\text { advantages. Strengthening of the personal success. }\end{array}$ \\
\hline
\end{tabular}

The observance of actions, corresponding to certain position will allow to provide successful realization of «blue ocean» strategy.

\section{Results and discussions}

\section{Determination of factors of success and challenges}

Approbation of offered methodology came true on the example of brewing industry of Ukraine, but can be used for any industry in other countries.

For determination of factors that have an influence on industry, were taken for basis reviews of brewing products markets and statistical information on their development [19, $20,21]$. The conducted analysis allowed to define challenges and success, and also execute their quantitative evaluation $[19,20,21,22,24]$. It is appeared, that industry had 13 factors of success and 19 factors that stipulated challenges for it (Table 2).

The analogical method the factors of success and challenges for Private joint stock company «Obolon» was determined [19, 20, 21]. Conducting the analysis of activity of the enterprise at the market, 15 factors that belong to the challenges of the company, and 8 factors of success, were educed.

Factors that stipulate challenges for Private joint stock company «Obolon» are: falling of production and consumption of beer volumes in Ukraine; difficult macroeconomic situation in the country; devaluation of national currency; absence of political stability; small social guarantees for highly skilled specialists; low level of integration of science and production; decline of purchasing power of population; reduction of consumption level of beer of average price segment; increase of beer consumption in the economy segment; large concentration of market; increase of excise on beer; including of beer to the list of alcoholic beverages in accordance with changes in the Internal Revenue Code; competition with the producers of strong alcohol; reduction of beer export to Russia; increasing of price on raw material $[19,20,21,22]$. 
Challenges and success of brewing industry of Ukraine

\begin{tabular}{|c|c|}
\hline Challenges & Success \\
\hline $\begin{array}{l}\text { 1. Falling of production and consumption } \\
\text { of beer volumes in Ukraine }\end{array}$ & $\begin{array}{l}\text { 1. Presence of foreign investments in } \\
\text { industry }\end{array}$ \\
\hline $\begin{array}{l}\text { 2. Difficult macroeconomic situation in } \\
\text { the country }\end{array}$ & $\begin{array}{l}\text { 2. Introduction of progressive technologies } \\
\text { of production of new types of products - } \\
\text { unfiltered, icy, fruit, «living» beer }\end{array}$ \\
\hline 3. Devaluation of national currency & 3. Growing demand on «living» beer \\
\hline 4. Absence of political stability & $\begin{array}{l}\text { 4. Increase of popularity of «authorial» } \\
\text { products of small brewing plants }\end{array}$ \\
\hline 5. Presence of local conflict & $\begin{array}{l}\text { 5. Noticeable increase of beer sale in the } \\
\text { restaurant business }\end{array}$ \\
\hline $\begin{array}{l}\text { 6. Small social guarantees for scientists } \\
\text { and highly skilled specialists }\end{array}$ & $\begin{array}{l}\text { 6. Change of consumers' tastes to the } \\
\text { consumption of the unpasteurized beer } \\
\text { in kegs }\end{array}$ \\
\hline $\begin{array}{l}\text { 7. Low level of integration of science and } \\
\text { production }\end{array}$ & $\begin{array}{l}\text { 7. Increase of popularity of the «craft» } \\
\text { brewing }\end{array}$ \\
\hline $\begin{array}{l}\text { 8. Decline of purchasing power of } \\
\text { population }\end{array}$ & $\begin{array}{l}\text { 8. Change in the culture of alcohol } \\
\text { consumption: increase of beer } \\
\text { consumption and reduction of vodka } \\
\text { consumption, and also consumption in } \\
\text { the place of its production }\end{array}$ \\
\hline $\begin{array}{l}\text { 9. Reduction of consumptions level of } \\
\text { trade marks, that is presented in a } \\
\text { middle price segment }\end{array}$ & $\begin{array}{l}\text { 9. Increase of beer consumption in } \\
\text { premium segment }\end{array}$ \\
\hline $\begin{array}{l}\text { 10. Increase of consumption of beer in the } \\
\text { economy segment }\end{array}$ & $\begin{array}{l}\text { 10. Adaptation of enterprises to the work on } \\
\text { foreign malt and hop }\end{array}$ \\
\hline 11. Large concentration of market & $\begin{array}{l}\text { 11.Introduction of energy saving } \\
\text { technologies of beer production }\end{array}$ \\
\hline 12. High entrance barriers in industry & $\begin{array}{l}\text { 12. Appearance of new harmless for nature } \\
\text { types of packing }\end{array}$ \\
\hline $\begin{array}{l}\text { 13. Absence of prospects of development } \\
\text { of small brewing plants }\end{array}$ & 13.Improving of the new markets of sale \\
\hline \multicolumn{2}{|l|}{ 14. Increase of excise on beer } \\
\hline \multicolumn{2}{|l|}{$\begin{array}{l}\text { 15. Including of beer to the list of alcoholic } \\
\text { beverages in accordance with the } \\
\text { changes in the Internal Revenue Code }\end{array}$} \\
\hline \multicolumn{2}{|l|}{$\begin{array}{l}\text { 16. Competition with the producers of } \\
\text { strong alcohol }\end{array}$} \\
\hline \multicolumn{2}{|l|}{ 17. Reduction of beer export to Russia } \\
\hline \multicolumn{2}{|l|}{$\begin{array}{l}\text { 18. Low level of introduction of } \\
\text { information technologies in industry }\end{array}$} \\
\hline $\begin{array}{l}\text { 19. Increasing of price advance on raw } \\
\text { material }\end{array}$ & \\
\hline
\end{tabular}
It is made on the basis of own researches and the sources [19, 20, 21, 22, 23, 24]. 
Success for Private joint stock company «Obolon» are: introduction of progressive technologies of production of new types of products - unfiltered, icy, fruit, «living» beer; noticeable increase of sale of beer is in the restaurant business; change in the culture of alcohol consumption; increase of beer consumption and reduction of vodka consumption, and also consumption in the place of its production; increase of beer consumption in premium segment; introduction of energy saving technologies of beer production; appearance of new harmless for nature types of packing; improving the new markets of sale [22, 23, 24].

\section{Evaluation of factors of successes and challenges}

According to the factors of industry, given in table 2 and by factors recommended for the enterprise, the state of each factors by questioning of experts was appraised. 5 leading specialists of brewing industry and Private Joint Stock «Obolon» came forward is the state of factors.

The experts' opinions got as the result of questioning were average, and also checked for coordination by means of coefficient of variation, that in relation to the challenges of industry is confirmed by Table 3 .

Table 3

Results of experts' opinions verification on coordination and their middle values after the factors of challenges of brewing industry

\begin{tabular}{|c|c|c|c|c|c|c|c|}
\hline \multirow{2}{*}{ № } & \multicolumn{5}{|c|}{ Experts estimations } & \multirow{2}{*}{$\begin{array}{c}\text { Coefficient of } \\
\text { variation, } \%\end{array}$} & \multirow{2}{*}{$\begin{array}{l}\text { Average value of } \\
\text { expert estimations }\end{array}$} \\
\hline & 1 & 2 & 3 & 4 & 5 & & \\
\hline 1 & 5 & 4 & 5 & 5 & 5 & 8,33 & 4,8 \\
\hline 2 & 4 & 5 & 4 & 4 & 4 & 9,52 & 4,2 \\
\hline 3 & 3 & 3 & 2 & 4 & 3 & 21,08 & 3 \\
\hline 4 & 2 & 2 & 4 & 3 & 3 & 26,73 & 2,8 \\
\hline 5 & 2 & 3 & 2 & 2 & 2 & 18,18 & 2,2 \\
\hline 6 & 1 & 2 & 2 & 2 & 2 & 22,22 & 1,8 \\
\hline 7 & 2 & 3 & 3 & 3 & 3 & 14,29 & 2,8 \\
\hline 8 & 5 & 5 & 5 & 5 & 5 & 0 & 5 \\
\hline 9 & 2 & 4 & 4 & 3 & 3 & 23,39 & 3,2 \\
\hline 10 & 4 & 4 & 3 & 3 & 3 & 14,41 & 3,4 \\
\hline 11 & 3 & 4 & 4 & 5 & 5 & 17,82 & 4,2 \\
\hline 12 & 4 & 4 & 3 & 4 & 4 & 10,53 & 3,8 \\
\hline 13 & 2 & 4 & 4 & 4 & 4 & 22,22 & 3,6 \\
\hline 14 & 4 & 4 & 3 & 3 & 3 & 14,41 & 3,4 \\
\hline 15 & 3 & 4 & 4 & 4 & 4 & 10,53 & 3,8 \\
\hline 16 & 3 & 3 & 2 & 4 & 3 & 21,08 & 3 \\
\hline 17 & 1 & 1 & 2 & 2 & 2 & 30,62 & 1,6 \\
\hline 18 & 3 & 2 & 2 & 3 & 3 & 18,84 & 2,6 \\
\hline 19 & 3 & 3 & 3 & 3 & 3 & 0 & 3 \\
\hline
\end{tabular}

By analogical method the evaluation and checking for homogeneity for the factors of industry success was conducted (Table 4). 
Table 4

Results of experts' opinions verification on coordination and their middle values after the factors of successes of brewing industry

\begin{tabular}{|c|c|c|c|c|c|c|c|}
\hline \multirow{2}{*}{ No } & \multicolumn{6}{|c|}{ Experts estimation } & \multicolumn{2}{c|}{$\begin{array}{c}\text { Coefficient of } \\
\text { variation, \% }\end{array}$} & $\begin{array}{c}\text { Average value of } \\
\text { expert estimations }\end{array}$ \\
\cline { 2 - 6 } & $\mathbf{1}$ & $\mathbf{2}$ & $\mathbf{3}$ & $\mathbf{4}$ & $\mathbf{5}$ & & 4,6 \\
\hline 1 & 4 & 5 & 5 & 4 & 5 & 10,65 & 5,0 \\
\hline 2 & 5 & 5 & 5 & 5 & 5 & 0 & 4,4 \\
\hline 3 & 5 & 4 & 5 & 5 & 3 & 18,18 & 2,8 \\
\hline 4 & 2 & 3 & 3 & 3 & 3 & 14,29 & 1,6 \\
\hline 5 & 2 & 1 & 2 & 2 & 1 & 30,62 & 2,8 \\
\hline 6 & 3 & 2 & 3 & 3 & 3 & 14,29 & 2,6 \\
\hline 7 & 2 & 3 & 3 & 2 & 3 & 18,84 & 3,8 \\
\hline 8 & 3 & 4 & 4 & 4 & 4 & 10,53 & 3,2 \\
\hline 9 & 4 & 4 & 4 & 5 & 4 & 9,52 & 3,4 \\
\hline 10 & 4 & 3 & 3 & 4 & 3 & 14,41 & 4,8 \\
\hline 11 & 3 & 3 & 3 & 4 & 4 & 14,41 & 3,6 \\
\hline 12 & 5 & 5 & 4 & 5 & 5 & 8,33 & 13,61 \\
\hline 13 & 4 & 3 & 4 & 4 & 3 & & \\
\hline
\end{tabular}

For every factor (both for group of challenges and success) thecoefficient of variation is less than normative value (33\%), thus totality of opinions of this group of experts can be considered homogeneous and use for further researches [29, 30].

Grouping of factors was farther carried out after the degree of importance (table 5). Determination of coefficients of importance was based on own researches of the state of brewing industry and results of working corresponding sources [19, 20, 21, 23, 24].

Table 5

Grouping of factors after the degree of importance and distribution of coefficients of importance

\begin{tabular}{|l|c|l|c|}
\hline $\begin{array}{c}\text { Groups of challenges } \\
\text { factors of brewing industry }\end{array}$ & $\begin{array}{c}\text { Coefficient } \\
\text { of } \\
\text { importance }\end{array}$ & $\begin{array}{l}\text { Groups of success factors } \\
\text { of brewing industry }\end{array}$ & $\begin{array}{c}\text { Coefficient of } \\
\text { importance }\end{array}$ \\
\hline $1,2,8$ & 0,08 & $1,2,8,11$ & 0,09 \\
\hline $3,4,11$ & 0,07 & $3,10,12,13$ & 0,08 \\
\hline $6,10,12$ & 0,06 & 4,7 & 0,07 \\
\hline 13,14 & 0,05 & $5,6,9$ & 0,06 \\
\hline $7,15,16,19$ & 0,04 & - & - \\
\hline $9,17,18$ & 0,03 & - & - \\
\hline 5 & 0,02 & - & - \\
\hline
\end{tabular}

It is made on the basis of own researches and source [19, 20, 21, 23, 24]. 
Using these tables 3, 4, 5 it was the certainly generalized average estimation of factors of challenges and success of brewing industry.

On counts, success of industry got a general estimation that equals 3,72 points. The quantitative value of challenges presented 3,48 points. Such estimation can be considered moderate, because it is considerably less than 5 points. It testifies that industry has large backlogs for development.

By the analogical method the evaluation of certain factors of Private joint stock company «Obolon» was conducted by bringing workers of higher and middle ranks of management of the enterprise. Calculations showed that the quantitative estimation of success of the enterprise at the market had laid down 4,55, and challenges are 3,11 points. The got results are quite good enough. Although after the amount of success less than challenges, but their estimation is approached to 5 points. Challenges in number anymore and measuring results testify to their danger for the enterprise. Desirable is the value that is approached to 1 .

Determination of position of industry/ enterprise for finding out of readiness of Private joint stock company «Obolon» to introduction of «blue ocean» strategy

For comfort presentation of analysis results of industry position and enterprise the «success-challenges» (Figure 2) shown on matrix by the mark of IP (Industry Position) and CP (Company Position) accordingly.

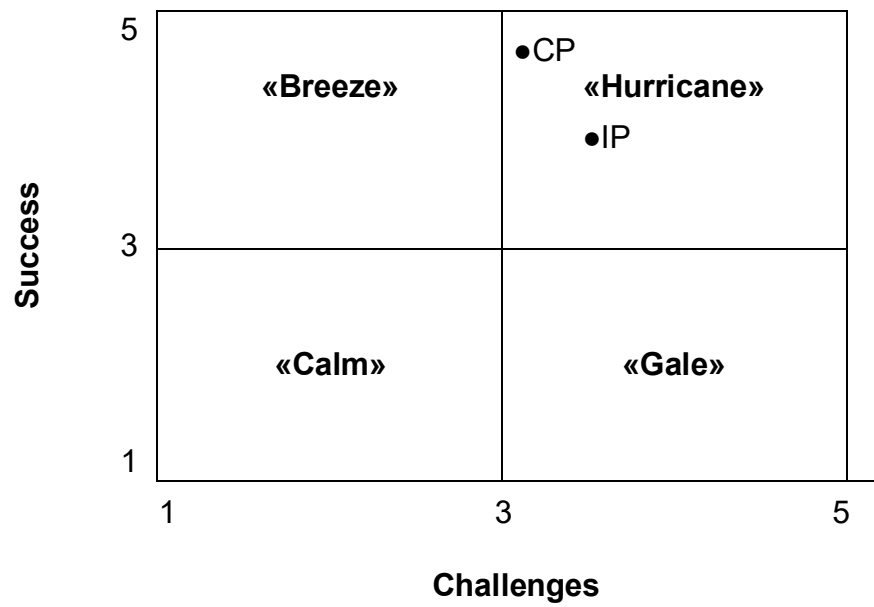

Figure 2. Position of brewing industry and Private joint stock company «Obolon» on matrix «success-challenges», developed by authors

On results of research position of industry and company on the field of matrix answers a quadrant «Hurricane». It testifies the necessity of immediate cardinal changes, while for this purpose there are comfortable terms at a minimum risk. In the near future appearance of urgent requirement is expected in the search of the non-standard approach development of industry and enterprise (for example, introduction of new types of products with unique 
descriptions, new teachnologies, non-standard methods of communications and others). But there are no obstacles to introduction of strategy of blue ocean.

Position of company (CP) on the field of matrix «success-challenges» (Figure 2) also «Hurricane» answers a quadrant and testifies to the large challenges. Therefore, passing to introduction of «blue ocean» strategy is desirable.

Without regard to that position of both industry and company got to one to the quadrant, it is necessary to mark that position of Private joint stock company «Obolon» is better than position of brewing industry on the whole: the quantitative estimation of success of the enterprise presents 4,55, and industries are 3,72 points. Challenges for the enterprise far fewer $(3,11)$ in comparing to industry $(3,48)$. There was a situation that answers two terms: from one side, strategic position of industry is approximately identical to position of company, from other - position of the enterprise looks more successful in comparing to industry. Thus, Private joint stock company «Obolon» can be considered ready to introduction of «blue ocean» strategy.

\section{Conclusions}

Thus, as the result of undertaken study, the methodical approach to the determination of readiness of introduction of «blue ocean» strategy on the enterprise, is firstly given, the use of that will allow:

- To make more balanced decision about creation of free market space;

- To elect the most optimal direction of introduction strategy;

- To form reasonably the program of actions and events for realization of «blue ocean» strategy.

The scientific value of the worked out methodology consists in possibility of determination of strategic position of industry/company by establishment and quantitative measuring of factors, that have both positive and negative influence, and also research of the level of company's readiness to perception of «blue ocean» strategy. Thus, select factors go into details intoof three directions: features of the enterprise, specific of industry and market situation. Offered methodology is enriched by authorial matrix «success-challenges» (each of its quadrants is characterised).

Unlike existing, the presented methodology is based on marketing researches, factor analysis, use of method of expert estimations and allows not only to define readiness of the enterprise to introduction of «blue ocean» strategy but also envisage actions in direction of motion to such space.

Application of offered methodical approaches will assist more comfort passing to the menage on principles of «blue ocean» conception, that will allow to avoid complete or partial influence of competition on activity of industry or company and will give the opportunity to free the financial resources related to realization of marketing researches of competitors and competition situation. The further prospect of research can be consideration and choice of additional analytical instruments and models that will help the enterprise to form new own market space.

\section{References}

1. Lambin J.-J. (2007), Market-Driven Management: Strategic and Operational Marketing, Palgrave Macmillan; 2nd edition, Bristol, United Kingdom. 
2. Jacobs R. (1997), Real-Time Strategic Change Published, Berrett-Koehler Publishers, Oakland, California.

3. Kotter J., Schlesinger L. (2008), Choosing strategies for change, Harvard Business Review, 8, pp. 130, 132-139.

4. Gamble P., Tapp A., Marsella A., Stone M. (2005), The Marketing Revolution: The Radical New Way to Transform the Business, the Brand and the Bottom Line, Kogan Page Business Books, London.

5. Jouret G. (2009), Inside Cisco's search for the next big idea, Harvard Business Review, 9, pp. 43-45.

6. Kotler P., Caslione J. (2009), Chaotics: The Business of Managing and Marketing in the Age of Turbulence Hardcover, AMACOM, New York.

7. Kim W. C., Mauborgne R. (2005), «Blue Ocean Strategy: From Theory to Practice», California Management Review, 47(3), pp.105-121.

8. Kim W.C., Mauborgne R. (2004), Blue Ocean strategy, Harvard Business Review, 82 (10), pp. 76-85.

9. Buisson B., Silberzahn Ph. (2010), Blue Ocean Or Fast-Second Innovation? A Four Breakthrough Model To Explain Successful Market Domination, International Journal of Innovation Management, 14 (03), Available at: https://cutt.ly/uhWgy2V.

10. Kim W. C., Mauborgne R. (2015), Red ocean traps: The mental models that undermine market-creating strategies, Harvard Business Review, 3, pp. 68-73.

11. Carton G. (2020), How Assemblages Change When Theories Become Performative: The case of the Blue Ocean Strategy, Organization Studies, 10, pp. 1417-1439.

12. Iansiti M., Lakhani K. (2017), Managing our hub economy: Strategy, ethics, and network competition in the age of digital superpowers, Harvard Business Review, 9, pp. 84-92.

13. Kao J. (2009), Tapping the world's innovation hot spots. Harvard Business Review, 3, pp.109-114.

14. Kim W. C., Renee M. (2014). Blue ocean leadership. Are your employees fully engaged in moving your company forward? Here's how.. Harvard Business Review, 5, pp. 60-72.

15. Kim W.C., Mauborgne R. (2004), Blue Ocean Strategy: How to Create Uncontested Market Space and Make the Competition Irrelevant, Harvard Business School Press, Boston.

16. Salamander I.(2015), Blue Ocean Strategy, Special Edition, $p .37$.

17. Ignatius A. (2018), Businesses exist to deliver value to society, Harvard Business Review, 3 , pp. 82-87.

18. Kim, W. C., Mauborgne R. (2002), Charting your company's future, Harvard Business Review, 6, pp. 77-83.

19. (2018). Beer Business, Ukrainian beer market, Available at: https://journal.beer/2018/11/20/ukrainian-beer-market/

20. (2019). Beer Business, Ukrainian beer market, Available at: https://journal.beer/2019/11/10/beer-business-3-2019-ukrainian-beer-market-2019companies-and-brands/

21. (2019). Best Beers, Brewers, New Brewers By Country. Available at: https://www.ratebeer.com/RateBeerBest.

22. Betancura M., Motokib K., Spencec C., Velasco C. (2020), Factors influencing the choice of beer: A review, Food Research International, Available at: https://www.researchgate.net/publication/341680075_Factors_influencing_the_choice_of_ beer

23. Pryimachuk T., Protsenko A., Rudyk R., Shtanko T. (2018), Pyvna ta khmeleva haluzi Ukrainy: koniunktura ta intehratsiia, Visnyk ahrarnoi nauky, 4 (781), pp. 61-67, Available at: https://agrovisnyk.com/pdf/ua_2018_04_10.pdf. 
24. Kolbushkyn Y., Radchenko H., Tomchuk A. (2018), Osoblyvosti ta marketynhovi tendentsii rozvytku pyvovarnoi haluzi Ukrainy, Problemy systemnoho pidkhodu v ekonomitsi, 6 (68), pp. 205-210.

25. Patkar V. (2018), Research Methodology: Logic, Methods and Cases, Vikalpa: The Journal for decision maker, 43(3), pp. 175-177, DOI: 10.1177/0256090918796953.

26. Falkembach E., Carillo T. (2015), Systematization of Experiences: A Practice of Participatory Research from Latin America, 8, pp. 74-80, DOI: https://dx.doi.org/10.4135/9781473921290.n8

27. Pickvance C. (2001), Four Varieties of Comparative Analysis, Journal of Housingand the Built Environment,16(1), pp. 7-28, DOI: 10.1023/A:1011533211521

28. Shemilt I., Mugford M., Vale L., Marsh K., Donaldson C., Drummond M. (2010), Research Synthesis Methods, Europe PMC, 1(2), pp. 126-135, Available at: DOI:10.1002/jrsm.14.

29. Karasev O., Mukanina E. (2019), Metod jekspertnyh ocenok v forsajt-issledovanijah, Statistika i Economika, 16(4), pp. 4-13, DOI: 10.21686/2500-3925-2019-4-4-13

30. Bezpalko O., Krainiuchenko O. (2008), Vykorystannia metodu ekspertnykh otsinok v marketynhovykh doslidzhenniakh, Kharchova promyslovist, 7, pp. 128-132.

31. (2017), Economic policy uncertainty and sovereign credit rating decisions: Panel quantile evidence for the Eurozone, Journal of International Money and Finance, 79, pp. 39-71.

32. Almon C. (1967), Matrix Methods in Economics, Addison-Wesley Pub. Co., Massachusetts and London.

33. O'Gorman P. (2008), Wii: Creating a blue ocean the Nintendo way, Palermo Business Review, 2, pp. 97-108. 